\title{
Penile Cancer pN2 TNM Finding v8
}

National Cancer Institute

\section{Source}

National Cancer Institute. Penile Cancer pN2 TNM Finding v8. NCI Thesaurus. Code C140073.

Penile cancer with three or more unilateral inguinal metastases or bilateral metastases. (from AJCC 8th Ed.) 